\title{
The Validity of Android-Based Biology Teaching Materials to Improve Students' Concept Mastery
}

\author{
* Kurnia Dewi Rusdiana Putri, Muhlis, Agus Ramdani \\ Magister of Science Education Program, Universitas Mataram, Jl. Majapahit No.62, \\ Mataram, Indonesia, 83115 \\ *Corresponding Author e-mail: kurniadewiputri97@gmail.com
}

Received: July 2021; Revised: September 2021; Published: December 2021

\begin{abstract}
This study aims to develop appropriate android-based teaching materials to improve students' mastery of concepts. This study is a qualitative descriptive study to assess and obtain the quality of a valid android-based learning material knowledge instrument to improve students' conceptual mastery skills. In addition to developing android-based biology teaching materials, researchers also develop a syllabus, lesson plans (RPP), and students' concept mastery instruments. Data collection techniques use validation sheets by three expert lecturers who are competent in their field. The data analysis technique uses the Aiken'V index. The results of the feasibility test show that: 1) android-based biology teaching materials (0.83); 2) Syllabus (0.82); 3) RPP $(0.82)$; and 4$)$ concept mastery instruments $(0.78)$ categorized as very valid and valid criteria. In conclusion, this android-based biology teaching material is feasible to be applied and implemented in learning.
\end{abstract}

Keywords: Validity; Teaching materials; Biology; Androids; Concept mastery

How to Cite: Putri, K., D., R., Muhlis, M., \& Ramdani, A. (2021). The Validity of Android-Based Biology Teaching Materials to Improve Students' Concept Mastery. Prisma Sains : Jurnal Pengkajian Ilmu dan Pembelajaran Matematika dan IPA IKIP Mataram, 9(2), 199-203. doi:https://doi.org/10.33394/j-ps.v9i2.4202

https://doi.org/10.33394/j-ps.v9i2.4202

Copyright $\odot$ 2021, Putri et al This is an open-access article under the CC-BY License.

\section{INTRODUCTION}

The limitations of time and space, which are often problems, can now be overcome with the presence of electronic-based learning or what is known as electronic learning (Sarah and Effendi, 2019). E-learning is an approach to facilitate and enhance learning through computer and communication technology (Kumar Basak et al., 2018). The use of inflexible electronic equipment is certainly one of the obstacles in implementing e-learning (Al-Azawei, et al., 2016). However, over time, technology continues to provide solutions for the world of education, one of which is a mobile-based learning system or what is known as mobile learning (Gideon, 2018). One of the considerations in developing smartphones into mlearning learning media is the basis for the operating system used (Aripin, 2018). The operating system is a liaison between applications and hardware so that users can carry out certain functions. The operating system widely used on smartphones and tablet PCs is Android (Ramdani, et al., 2020). Anggraeni and Kustijono (2013) Android is the most popular operating system in the community because it has advantages such as open-source nature that gives developers the freedom to create applications. Android is a mobile device operating system that is superior to Symbian and Windows Mobile (Sarah and Effendi, 2020).

Based on the results of observations that have been made in one of the public high schools in Narmada, West Lombok, learning is still teacher-centered. Learning teaching materials that are often used are power points, learning videos, textbooks, and Student 
Worksheets (modules). In Biology lessons, the existing books are too thick, causing students to be lazy to read. These teaching materials cannot be used by students at any time and are considered less practical and make students feel bored. According to Hellsten and Nerlich (2011) biology is a science that is quite old because most of it stems from a human curiosity about themselves, their environment, and the continuity of their species. Biology is not just the mastery of a collection of knowledge in the form of facts, concepts, or principles but also a discovery process. The learning process focuses on providing direct experience to students to develop the ability to scientifically explore and understand the natural surroundings (Tanjung, 2016). Direct experience can be done through practical activities in the laboratory or observation activities to the natural surroundings. Observation activities sometimes have various obstacles, namely the lack of facilities, costs, and objects that are difficult to find. material and it is easier for students to understand the material being taught (Sarah and Effendi, 2019).

According to Shah (2010); Yustiquar, et al (2019), using the suitable media can increase students' interest in learning. The selection of the right and interesting media can focus intensive attention and arouse the interest of students to master the knowledge conveyed through the use of these media so that this can affect the quality of achieving student learning outcomes (Ramdani, et al., 2020). Furthermore, Hadisaputra et al. (2019; 2020) stated that students would feel motivated to listen to the information conveyed through the media. Furthermore, Hadisaputra et al. (2019) stated that interactive multimedia-based learning media could improve students' mastery of concepts.

The development of android-based media is expected so that students' mastery of concepts can be achieved increase. Learning by using learning media allows participants teach to focus on content. Learning media contains media elements complete which includes animated audio, video, text, and graphics that allow users to interact interactively through the available features (Gunawan, et al., 2017).

Cole \& Todd (2003) stated that interactive media can provide a response positive and increase students' interest in learning which is shown in the evaluation results very high learning and very good learning activities, this is also supported by research from Kamlaskar (2007) which states that respondents with a percentage of $80 \%$ said interactive multimedia was interesting and fun. This study aims to develop appropriate android-based biology teaching materials to improve students' mastery of concepts.

\section{METHOD}

This study is a qualitative descriptive study to assess and obtain the quality of a valid android-based learning material knowledge instrument to improve students' conceptual mastery skills.

Three expert validators carried out the learning device validity test by filling out the validation sheet. Expert validators consist of media experts, material experts and language experts. Furthermore, validators are asked to provide general assessments and suggestions for the developed Android-based mobile learning learning media, whether the Android-based mobile learning learning media that have been made can be said to be valid or invalid. The expert validation data were analyzed to determine the level of validity using the Aiken's V formula (1985). The level of validity is determined based on Table 1.

Table 1. Validity Level

\begin{tabular}{ll}
\hline Value Range & Category \\
\hline $\boldsymbol{V} \leq \mathbf{0 . 4}$ & Low Validity \\
$\mathbf{0 . 4}>\boldsymbol{V}<\mathbf{0 . 8}$ & Medium Validity \\
$\boldsymbol{V} \geq \mathbf{0 . 8}$ & High Validity \\
\hline
\end{tabular}




\section{RESULTS AND DISCUSSION}

The product resulting from this development research is in the form of an Androidbased teaching material application. In addition to developing android-based teaching materials, researchers also developed syllabus, lesson plans, and instruments for mastering student concepts. This learning product was created and designed by the researcher himself to be able to be used as a teacher's tool in delivering material and as an independent learning resource that students can use at any time outside of school.

Before being tested on research subjects, the initial design of android-based teaching materials must be validated first by experts. The aim is to determine the feasibility of the initial design of the Android-based teaching materials. The results of the design of androidbased biology teaching materials are presented in Figure 1.

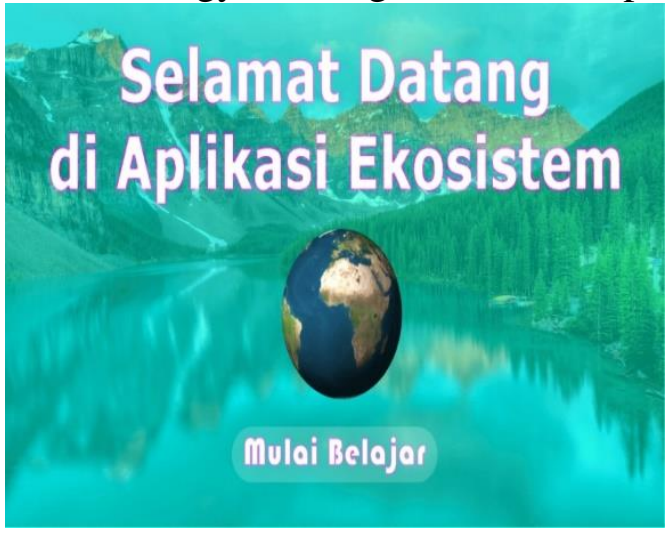

a. Homepage

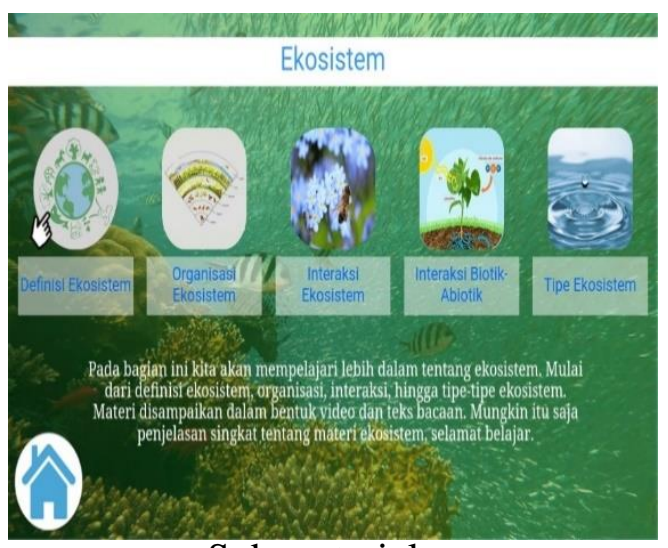

c. Sub material page

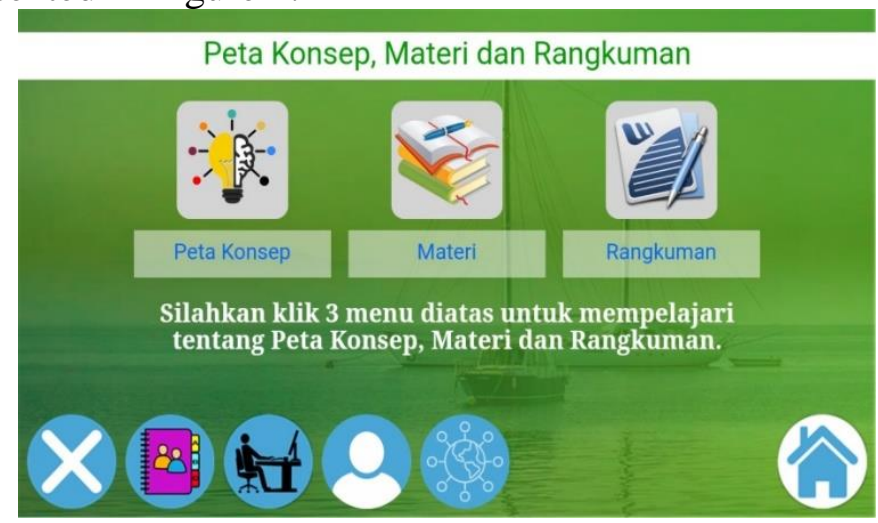

b. Material page

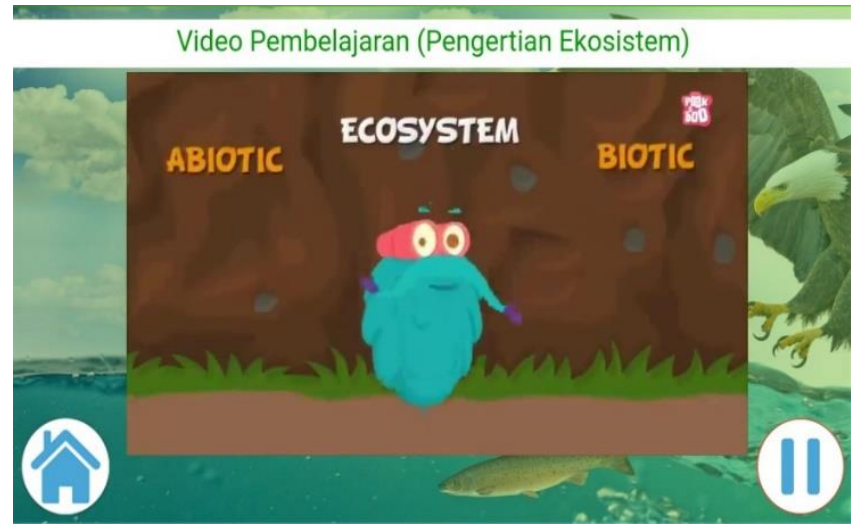

d. Learning video page

Figure 1. The results of the development of android-based biology teaching materials

Validation was carried out by expert lecturers consisting of material expert lecturers, media expert lecturers, and language expert lecturers. At the design stage, the following are 1) designing an android-based teaching material application; 2) Materials, pictures, and videos that are appropriate and appropriate to biological materials, 3) Validation sheets for media experts and material experts. The Development stage results from the development stage, namely: 1) Android-based learning media applications, this application consists of student competencies, teaching materials, pictures, videos, sample questions, and interactive evaluation questions; 2) Media validation score. The validation results are presented in Table 2.

Table 2. Learning Product Validation Results

\begin{tabular}{clll}
\hline No & Learning Products & Value & Criteria \\
\hline 1 & Android-based teaching materials & 0.83 & Very Valid \\
2 & Syllabus & 0.82 & Very Valid \\
\hline
\end{tabular}




\begin{tabular}{clll}
\hline No & Learning Products & Value & Criteria \\
\hline 3 & Lesson Plan & 0.82 & Very Valid \\
4 & Instrument & 0.72 & Valid \\
Average & $0.81,25$ & Very Valid \\
\hline
\end{tabular}

Based on the results of Table 1, referring to the validity category, the results of the validity, and the validity category, the validity results of learning products are included in the very valid category. This indicates that the learning product is feasible to use in biology learning. This study is in line with the opinion expressed by Liu, et al. (2009); Greenhow and Lewin (2016); Gunawan et al (2021); learning media can be used as a source of independent learning by students, learning can be done anytime and anywhere. Learning using androidbased biology teaching materials is not limited only in class but can be done outside the classroom.

Based on the validity of android-based teaching materials, it can be concluded that the developed android-based teaching materials are valid. According to Latif \& Hidayatullah (2019), there are several aspects of the validity of teaching materials as follows: (1) In terms of format, that is, each section is presented clearly, shows consideration between text and illustrations, is visually quite attractive and uses clear and simple sentence structures; (2) In terms of language, namely the language used in accordance with the ability of students to be easily understood, using clear and simple word choices, and using clear and simple sentence structures; (3) The illustration aspect is clear, easy to understand, supports the concept so that it is easy to understand, and relates to the student's environment. (4) In terms of content, it contains important related information, logically arranged parts, and the truth of the contents.

Several things still need to be addressed even though they are included in the very feasible category and declared very valid, as suggested by the validator. First, in the syllabus, it is recommended to adjust the time allocation that is relevant to the activities to be carried out and tidy up the column display to make it look neat. In the lesson plan it is recommended to adapt the learning method to the model used, in each picture include a description of the picture and references and pay attention to the activity of formulating hypotheses, students must have prior knowledge to formulate it. In android-based teaching materials, it is recommended to adjust. There are still words that do not match the EYD as above, they should be above and the appearance of the writing is still too small. In the concept mastery instrument, it is recommended to use simple language so that it is easy to understand and there are still misconceptions in some questions. After getting suggestions from the validator, the researchers then made revisions according to these suggestions, so that the results of the validation of learning products with very practical criteria were obtained.

\section{CONCLUSION}

Android-based biology teaching materials developed are suitable for use in learning. This is evidenced by the acquisition of an average score of learning products equal to $81.25 \%$ with very valid criteria.

\section{RECOMMENDATION}

Android-based biology teaching materials developed are suitable for use in learning. This android-based biology teaching material that is produced can be an alternative learning resource that teachers in teaching apply.

\section{REFERENCES}

Aiken, L. R. (1985). Three coefficients for analyzing the reliability and validity of ratings. Educational and psychological measurement, 45(1), 131-142.

Al-Azawei, A., Parslow, P., \& Lundqvist, K. (2016). Barriers and opportunities of e-learning implementation in Iraq: A case of public universities. The International Review of Research in Open and Distributed Learning, 17(5). 
Anggraeni, R. D., \& Kustijono, R. (2013). Pengembangan media animasi fisika pada materi cahaya dengan aplikasi flash berbasis android. Jurnal Penelitian Fisika Dan Aplikasinya (JPFA), 3(1), 11-18.

Aripin, I. (2018). Konsep dan aplikasi mobile learning dalam pembelajaran biologi. Jurnal Bio Educatio, 3(1), 01-09.

Gideon, S. (2018). Peran media bimbingan belajar online "Ruangguru" dalam pembelajaran IPA bagi siswa SMP dan SMA masa kini: Sebuah pengantar. Jurnal Dinamika Pendidikan, 11(2), 167-182.

Greenhow, C., \& Lewin, C. (2016). Social media and education: Reconceptualizing the boundaries of formal and informal learning. Learning, media and technology, 41(1), 6-30.

Gunawan, G., Purwoko, A. A., Ramdani, A., \& Yustiqvar, M. (2021). Pembelajaran menggunakan learning management systemberbasis moodle pada masa pandemi covid-19. Indonesian Journal of Teacher Education, 2(1), 226-235.

Hadisaputra, S., Gunawan, G., \& Yustiqvar, M. (2019). Effects of Green Chemistry Based Interactive Multimedia on the Students' Learning Outcomesand Scientific Literacy. Journal of Advanced Research in Dynamical and Control Systems, 11(7), 664-674.

Hadisaputra, S., Ihsan, M. S., \& Ramdani, A. (2020, March). The development of chemistry learning devices based blended learning model to promote students' critical thinking skills. In Journal of Physics: Conference Series (Vol. 1521, No. 4, p. 042083). IOP Publishing.

Hellsten, I., \& Nerlich, B. (2011). Synthetic biology: building the language for a new science brick by metaphorical brick. New Genetics and Society, 30(4), 375-397.

Kumar Basak, S., Wotto, M., \& Belanger, P. (2018). E-learning, M-learning and D-learning: Conceptual definition and comparative analysis. E-learning and Digital Media, 15(4), 191-216.

Latif, M. A., Ainy, C., \& Hidayatullah, A. (2019). Pengembangan Bahan Ajar Berbentuk Komik Matematika Berbasis Android Dengan Pendekatan Rme. Jurnal Pendidikan Matematika (JPM), 6(1), 44-52.

Liu, S. H., Liao, H. L., \& Pratt, J. A. (2009). Impact of media richness and flow on e-learning technology acceptance. Computers \& Education, 52(3), 599-607.

Ramdani, A., Jufri, A. W., \& Jamaluddin, J. (2020). Pengembangan Media Pembelajaran Berbasis Android pada Masa Pandemi Covid-19 untuk Meningkatkan Literasi Sains Peserta Didik.Jurnal Kependidikan: Jurnal Hasil Penelitian dan Kajian Kepustakaan di Bidang Pendidikan, Pengajaran dan Pembelajaran, 6(3), 433-440.

Sarah, R. A. P., \& Effendi, Z. M. (2019). Pengembangan Mobile Learning Berbasis Android Pada Mata Pelajaran Biologi Kelas X Sma. Wahana Didaktika: Jurnal Ilmu Kependidikan, 17(3), 356-365.

Sarah, R. A. P., \& Effendi, Z. M. (2020). Pengembangan Mobile Learning Berbasis Android Pada Mata Pelajaran Biologi Kelas X SMA. Jurnal Penelitian IPTEKS, 5(1), 71-77.

Syah, M. (2010). Psikologi Pendidikan, Bandung: PT. Remaja Rosdakarya.

Tanjung, I. F. (2016). Guru dan strategi inkuiri dalam pembelajaran biologi. Jurnal Tarbiyah, 23(1).

Yustiqvar, M., Hadisaputra, S., \& Gunawan, G. (2019). Analisis penguasaan konsep siswa yang belajar kimia menggunakan multimedia interaktif berbasis green chemistry. Jurnal Pijar Mipa, 14(3), 135-140. 